\title{
Skrining Konsorsium Azotobacter Penghasil Fosfatase
}

\author{
Rachma Shouma Annisa dan Enny Zulaika \\ Departemen Biologi, Fakultas Ilmu Alam, Institut Teknologi Sepuluh Nopember (ITS) \\ e-mail: enny@bio.its.ac.id
}

\begin{abstract}
Abstrak-Fosfat tersedia di dalam tanah diperlukan oleh tanaman. Fosfat terlarut dapat disediakan oleh mikroorganisme melalui sekresi asam organik atau secara enzimatik dengan fosfatase. Beberapa anggota genus Azotobacter dapat melarutkan fosfat, namun belum diketahui apakah secara konsorsium dapat menghasilkan enzim fosfatase. Skrining Azotobacter penghasil fosfatase dilakukan dengan medium agar minimal (MM) yang dimodifikasi dengan penambahan p-nitrofenol fosfat (pNPP) sebagai sumber fosfat. Subkultur isolat menggunakan MM broth. Konsorsium Azotobacter A1b, A3, A6, A9, dan A10 mampu memproduksi enzim fosfatase.
\end{abstract}

Kata Kunci-Aktivitas Enzim, Fosfatase, Azotobacter, p-NPP.

\section{PENDAHULUAN}

$\mathrm{F}$ OSFOR (P) merupakan elemen penting yang tergolong dalam makronutrien yang diperlukan oleh tanaman dalam jumlah banyak [1]. Ketersediaan $\mathrm{P}$ dalam tanah pada umumnya rendah. Hal ini disebabkan $\mathrm{P}$ terikat menjadi $\mathrm{Fe}-$ fosfat dan Al-fosfat pada tanah masam dan $\mathrm{Ca} 3(\mathrm{PO}) 4$ pada tanah basa [2]. Tanaman tidak dapat menyerap $\mathrm{P}$ dalam bentuk terikat sehingga harus dirubah menjadi bentuk tersedia bagi tanaman $\left(\mathrm{H}_{2} \mathrm{PO}_{4}^{-}, \mathrm{HPO}_{4}{ }^{2-}\right.$, dan $\left.\mathrm{PO}_{4}{ }^{2-}\right)$ [3]. Bakteri tanah dapat berperan melarutkan $\mathrm{P}$ terikat, melalui sekresi asam organik [4] dan produksi enzim fosfatase [5].

Bakteri tanah seperti bakteri pelarut fosfat memiliki kemampuan melarutkan $\mathrm{P}$ terikat menjadi $\mathrm{P}$ terlarut yang dibutuhkan oleh tanaman. Bakteri tanah yang diketahui memiliki kemampuan tersebut salah satunya adalah genus Azotobacter [6]. Mikroba tanah menghasilkan enzim fosfatase basa dalam lingkungan basa dan sebaliknya akan menghasilkan enzim fosfatase asam dalam lingkungan asam [7]. Enzim fosfatase bertanggung jawab dalam proses hidrolisis $\mathrm{P}$ terikat menjadi $\mathrm{P}$ terlarut yang tersedia bagi tanaman [2]. Aktivitas enzim fosfatase dapat ditentukan dengan penggunaan fosfat hasil mineralisasi esterfosfat organik alami atau komponen organik buatan seperti pnitrofenol fosfat (pNPP) sebagai substrat. Penggunakan pNPP sebagai substrat akan menginduksi produksi fosfatase serta mengindikasikan kemampuan hindrolisis $\mathrm{P}$ terikat oleh fosfatase [8].

Pada penelitian sebelumnya [9] telah didapatkan potensi Azotobacter A1b, A3, A6, A9, dan A10 dari lahan Eco Urban Farming secara individual dan konsorsium mampu melarutkan fosfat sebesar 199,2-226,9 ppm. Namun, pelarutan fosfat tersebut belum diteliti potensinya secara sekresi asam organik atau enzimatis.

Berdasarkan penjelasan diatas, diperlukan penelitian lanjut apakah secara konsorsium dapat menghasilkan enzim fosfatase yang berfungsi melarutkan fosfat.

\section{METODOLOGI PENELITIAN}

\section{A. Waktu dan Tempat}

Penelitian dilakukan pada bulan Januari hingga Juni 2017 di Laboratorium Mikrobiologi dan Bioteknologi Jurusan Biologi, Fakultas Matematika dan Ilmu Pengetahuan Alam, Institut Teknologi Sepuluh Nopember Surabaya.

\section{B. Cara Kerja}

Penelitian ini terdiri atas dua tahapa skrining isolat Azotobacter menghasilkan fosfatase dan kurva pertumbuhan. Tahapan tersebut dijelaskan sebagai berikut:

\section{Skrining Isolat Azotobacter Menghasilkan Fosfatase}

Isolat Azotobacter diinokulasikan secara aseptis dalam medium minimal (MM) agar yang telah dimodifikasi sengan komposisi: potasium dihidrogen fosfat $\left(\mathrm{KH}_{2} \mathrm{PO} 4\right) 0,3$ gram, disodium hidrogen fosfat $\left(\mathrm{Na}_{2} \mathrm{HPO}_{4}\right)$ 0,6 gram, ammonium klorida $\left(\mathrm{NH}_{4} \mathrm{Cl}\right)$ 0,2 gram, sodium klorida $(\mathrm{NaCl})$ 0,5 gram, magnesium sulfat heptahidrat $\left(\mathrm{MgSO}_{4} .7 \mathrm{H} 2 \mathrm{O}\right)$, glukosa, agar 1,5 gram dan dilarutkan dalam $100 \mathrm{ml}$ akuades [10]. Inokulasi isolat dilakukan dengan menggunakan jarum ose secara aseptis dengan metode streak continue, diinkubasi dalam suhu ruang selama 24 jam [11]. Pertumbuhan isolat pada bekas goresan menunjukkan indikasi isolat mampu menghasilkan enzim fosfatase.

\section{Kurva Pertumbuhan}

Medium yang digunakan adalah medium minimal (MM) cair yang telah dimodifikasi dengan komposisi: potasium dihidrogen fosfat $\left(\mathrm{KH}_{2} \mathrm{PO} 4\right)$ 0,3 gram, disodium hidrogen fosfat $\left(\mathrm{Na}_{2} \mathrm{HPO}_{4}\right)$ 0,6 gram, ammonium klorida $\left(\mathrm{NH}_{4} \mathrm{Cl}\right) 0,2$ gram, sodium klorida $(\mathrm{NaCl}) \quad 0,5$ gram, magnesium sulfat heptahidrat $\left(\mathrm{MgSO}_{4} .7 \mathrm{H} 2 \mathrm{O}\right)$, glukosa, dan dilarutkan dalam $100 \mathrm{ml}$ akuades [10]. Selanjutnya $5 \mathrm{ml}$ konsorsium isolat (A3, A9, dan A10) ditambahkan dalam medium minimal cair sebanyak $585 \mathrm{~mL}$. Semua kultur diinkubasi pada rotary shaker (100 rpm) selama 48 jam dan dilanjutkan pengamatan kepadatan sel dengan spektrofotometri panjang gelombang $600 \mathrm{~nm}$ selama 48 jam [11].

\section{HASIL DAN PEMBAHASAN}

\section{A. Skrining Isolat Azotobacter Pada Medium Minimal}

Kelima isolat tunggal Azotobacter A1b, A3, A6, A9, dan A10 mampu tumbuh dalam medium minimal modifikasi (Tabel 1). Kemampuan isolat tumbuh dalam medium minimal mengindikasikan isolat mampu menghasilkan fosfatase. Selanjutnya isolat A3, A9, dan A10 dikonsorsiumkan. Seleksi terhadap ketiga isolat didasarkan pada pengamatan [9]. 
Tabel 1.

Hasil uji positif fosfatase isolat tunggal Azotobacter dalam medium minimal modifikasi

\begin{tabular}{ccc}
\hline \hline No & Isolat Azotobacter & Tumbuh \\
\hline 1. & A1b & + \\
2. & A3 & +++ \\
3. & A6 & + \\
4. & A9 & +++ \\
5. & A10 & +++ \\
\hline \hline
\end{tabular}
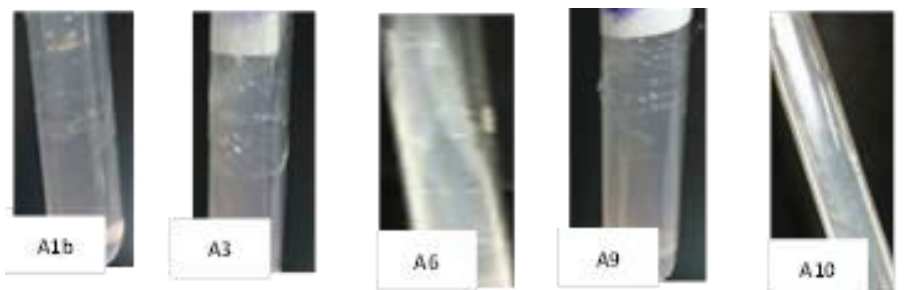

Gambar. 1. Hasil uji positif fosfatase isolat tunggal Azotobacter dalam medium minimal modifikasi.

Pengkonsorsiuman dilakukan untuk meningkatkan kemampuan Azotobacter dalam memproduksi enzim fosfatase. Pada penelitian [9], ketiga isolat tunggal Azotobacter A3, A9, dan A10 bersifat sinegisme sehingga ketiga isolat tersebut diharapkan dapat tumbuh bersama untuk menghasilkan enzim fosfatase.

\section{B. Kurva Pertumbuhan Azotobacter}

Pengamatan kurva pertumbuhan Azotobacter dilakukan selama 48 jam untuk mengetahui fase eksponensial. Pengamatan kurva pertumbuhan dilakukan untuk menentukan umur starter bakteri yang digunakan dalam memproduksi enzim fosfatase, fase yang digunakan untuk umur starter adalah rata-rata dari eksponensial awal dan akhir. Kurva pertumbuhan akhir yang dihasilkan, menunjukkan adanya 3 fase pertumbuhan yaitu fase lag, fase eksponensial, dan fase stasioner. Pada jam ke-0 hingga jam ke-2 terlihat isolat memasuki fase lag. Selanjutnya pada jam ke-4 hingga jam ke42 fase pertumbuhan yang terlihat adalah eksponensial. Sedangkan, pada jam ke-44 hingga jam ke-48 isolat memasuki fase stasioner.

Pada pengamatan, fase lag terlihat dikarenakan bakteri yang sebelumnya tumbuh dalam medium kaya nutrisi yaitu Nutrient Broth (NB) diinokulasikan kedalam medium yang mengandung sedikit nutrisi yaitu medium minimal (MM). Perbedaan lingkungan hidup menyebabkan bakteri membutuhkan waktu lebih untuk beradaptasi dengan lingkungan yang baru. Pada fase lag, bakteri akan memulai sintesis protein, ko-enzim, dan vitamin yang dibutuhkan untuk pertumbuhannya [12].

Selanjutnya pertumbuhan bakteri memasuki fase eksponensial yaitu fase pembelahan sel yang berlangsung secara cepat karena adanya peningkatan aktivitas metabolism dan replikasi DNA [12]. Pasa fase eksponensial sel berkembang secara optimum. Fase salanjutnya merupakan fase stasioner yaitu fase dimana metabolisme bakteri mulai melambat dan diikuti dengan melambatnya pembelahan sel. Perubahan dalam fase ini terjadi akibat perubahan lingkungan yang disebabkan kepadatan sel yang tinggi [13].

Pada fase stasioner terjadi akumulasi waste materials, senyawa metabolit yang bersifat toksik, dan senyawa inhibitor seperti antibiotik di dalam medium [12]. Pada pengamatan tidak terlihat adanya fase kematian, karena pengamatan hanya dilakukan sampai dengan 48 jam, sehingga fase kematian tidak didapatkan. Selain itu, kemampuan Azotobacter dalam memfiksasi nitrogen bebas menyebabkan kebutuhan nitrogen tidak terbatas dalam medium sehingga isolat dapat tetap hidup dengan cara memperpanjang fase stasioner meskipun sumber nitrogen dalam medium sudah habis [9].

Fase pertumbuhan yang didapat, dijadikan landasan dalam menentukan starter untuk produksi enzim fosfatase. Penentuan starter diambil dari kultur pada fase eksponensial, yaitu pada jam ke 20. Starter yang berada pada fase eksponensial dianggap paling optimal untuk produksi enzim fosfatase, karena selama fase eksponensial terjadi peningkatan massa sel dan massa sitoplasma, pertumbuhan dan pembelahan sel bakteri juga mengalami peningkatan yang cepat dengan doubling time kurang dari 20 menit [13].

\section{KESIMPULAN}

Isolat Azotobacter A1b, A3, A6, A9, dan A10 mampu menghasilkan fosfatase. Kemampuan tumbuh isolat menghasilkan fosfatase tertinggi adalah A3, A9, dan A10. Konsorsium Azotobacter A3, A9, dan A10 mampu menghasilkan enzim fosfatase.

\section{DAFTAR PUSTAKA}

[1] I. Mardad, S. Aurelio, and S. Abdelaziz, "Solubilization of Inorganic Phosphate and Production of Organic Acids By Bacteria Isolated from A Moroccan Mineral Phosphate Deposit," African J. Microbiol. Res., vol. 7, no. 8, pp. 626-635, 2013.

[2] L. Lal, Phosphate Biofertilizers. Agrotech Publication Academy, 2002.

[3] Suliasih and Rahmat, "Aktivitas Fosfatase dan Pelarut Kalsium Fosfat oleh beberapa Bakteri Pelarut Fosfat," J. Biodiversitas, vol. 8, no. 1, pp. 23-26, 2006.

[4] J. Cunningham and C. Kuiack, "Production Of Citric And Oxalic Acid And Solubilization Of Calsium Phosphate By Penicillium bilail," Appl. Environ. Microb., vol. 58, pp. 1451-1458, 1992.

[5] P. Ponmurugan and C. Gopi, "Distribution Pattern and Screening of Phosphate Solubilizing Bacteria Isolated from Different Food and Forage Crops," J. Agron. Asian Netw. Sci. Inf., vol. 5, no. 4, pp. 600-604, 2006.

[6] D. J. Jimenez, J. S. Montana, and M. M. Martinez, "Characterization of Free Nitrogen Fixing Bacteria Of The Genus Azotobacter In Organic Vegetable Grown Colombian Soil," Brazilian J. Microbiol., vol. 42, pp. 846-858, 2011.

[7] N. Widawati and S. S. Arif, I Made, "Aktivitas Pelarut Fosfat oleh Aktinomisetes yang Diisolasi dari Waigeo, Kepulauan Raja Ampat, Papua Barat," J. Biodiversitas, vol. 9, no. 2, pp. 87-90, 2008.

[8] M. A. Tabatabai, Methods of Soil Analysis: Soil Enzyme. USA: Wisconsin, 1982

[9] R. Irawan and E. Zulaika, "Potensi Konsorsium Azotobacter untuk Meningkatkan Ketersediaan Fosfat di Dalam Tanah," Institut Teknologi Sepuluh Nopember, 2016.

[10]M. Mahesh, R. Somashekhar, B. Preenon, and E. T. Puttaiah, "Optimization for the Production of Extracellular Alkaline Phosphatase from Proteus mirabilis," J. Bioproces Biotech, vol. 5, no. 3, pp. 1-5, 2015.

[11]J. P. Harley and L. M. Prescott, Laboratory Exercises in Microbiology. USA: Mc Graw Hill, 2002.

[12]M. D. Rolfe et al., "Lag Phase Is a Distinct Growth Phase That Prepares Bacteria for Exponential Growth and Involves Transient Metal Accumulation," Int. J. Bacteriol., vol. 194, no. 3, pp. 686-701, 2012.

[13]P. Bhattacharya and R. K. Jain, "Phosphorus Solubilizing Biofertilizers In Whirlpool of Rock Phosphate Challenges \& Opportunities," J. Plant, vol. 45, no. 10, pp. 45-72, 2000. 